\title{
Measles, Moral Regulation and the Social Construction of Risk: Media NARRATIVES OF “ANTI-VAXXERs" AND THE 2015 Disneyland OUtBReAK
}

\author{
Gabriela Capurro \\ JoSH GREENBERG \\ Eve Dubé \\ Michelle Driedger
}

Abstract. This paper examines media coverage of the 2014-15 measles outbreak that began at Disneyland and spread throughout the United States and into Canada and Mexico. Specifically, it focuses on the construction of 'anti-vaxxers' as a central character in the outbreak's unfolding narrative who came to represent a threat to public health and moral order. Although parents who hold strong anti-vaccine views are small in number, media representations of 'anti-vaxxers' as prominent figures fail to capture the broad range of views and behaviours that constitute what we today call 'vaccine hesitancy' and thus delimit our understanding of this increasingly complex health issue.

Keywords: Risk Communication; Vaccines; Moral Panic; Moral Regulation; Discourse Analysis; Outbreak

Résumé. Cet article examine la construction médiatique des " anti-vaccins » comme des menaces à la santé publique et à l'ordre moral. En s'appuyant sur les approches théoriques liées à la panique morale et la régulation morale, l'article examine la construction rhétorique des « anti-vaccins » dans les médias canadiens en lien avec l'éclosion de rougeole survenue en 2014-15 à dans le parc d'attraction de Disneyland. Notre analyse illustre que les parents qui refusent la vaccination sont dépeints comme des 'menaces populaires' dont l'identité, les valeurs et les caractéristiques sociodémographiques font l'objet d'inquiétudes et d'indignations morales. Bien qu'il y ait très peu de parents ayant de convictions fortes à l'encontre des vaccins, les représentations de ce groupe dans les médias ne permettent pas de rendre compte de toute la diversité des attitudes possibles à l'égard de la vaccination, ce que nous nommons aujourd'hui " l'hésitation à la vaccination ", limitant ainsi notre compréhension de ce problème de santé publique. Nous soutenons que les « anti-vaccins » présentés dans les descriptions 
médiatiques des éclosions de maladies évitables sont une catégorie d'analyse problématique qui articule une politique de régulation morale dans laquelle la panique morale une composante importante.

Mots clés: Communication des risques; Vaccins; Panique Morale; Régulation morale; Analyse du discours.

\section{INTRODUCTION}

$V^{\prime a t i n s e n}$ accines are among the most important public health interventions ever conceived. Prior to the introduction of mass childhood immunization, diseases like smallpox, measles, polio, and rubella, devastated families and communities, not only because of their high mortality rates but because of potential life-altering complications, including blindness, deafness, and brain damage (Riedel, 2005). The first mass immunizations were mandated in mid-nineteenth century England to protect against smallpox, and, by 1990, global vaccination rates against several illnesses had risen from less than 5 percent to 80 percent (Henderson, 1997). The threat of emerging infections such as novel influenzas (e.g., H5N1, H1N1), coronaviruses (MERS) and, most recently, Zika virus reinforces the importance of vaccination to protect public health, in Canada and around the world.

Yet, despite the "miracle of vaccination" (Henderson, 1997), since the invention of the smallpox vaccine, anxiety and fear from small numbers of parents about the risks that vaccination might entail have persisted. In part, this anxiety stems from the historical legacy of vaccines as a form of population control and the particular dangers associated with them (e.g. the fear that children could develop autism after being inoculated, or concerns about the potential toxicity of some vaccine ingredients, such as aluminum and thimerosal).

The first vaccine was developed to eradicate smallpox and carried considerable risks, including contracting the very disease it was intended to prevent (Hausman, Ghebremichael, Hayek, \& Mack, 2014). Children were cut with lancets on the arm and then developed blisters that had to be 'harvested'; thus infants were not only recipients of vaccine matter but its very incubators (Durbach, 2005: 3). In England, a compulsory vaccination policy was imposed in 1853 and the state penalized parents who failed to vaccinate their children. The origins of the anti-vaccination movement emerged in this context of health risk, medical innovation and state social control - opponents of vaccination decried the hazards of early immunization techniques and rejected 
compulsory immunization laws as a threat to their freedom (Blume, 2006; Durbach, 2005).

The vaccines of today are more effective and pose lower risks than they did a century and a half ago, yet opposition to vaccines persists. Parents who refuse vaccines for the most serious childhood diseases are a small but generally vocal group; a much larger and growing number of parents are better described as 'vaccine hesitant' (Dubé et al., 2013). While vaccine hesitant parents may ultimately have their children vaccinated, they do so with doubts about the benefits of vaccines, worry about their safety or question their necessity. Others believe young children are unable to withstand the number or frequency of vaccines and thus delay some vaccines while accepting others. (Greenberg, Dubé and Driedger, 2017).

Recent outbreaks of vaccine preventable diseases have thrust the issue of childhood immunization into the media spotlight in Canada and around the world. In 2011, a measles outbreak in Quebec infected more than 700 people. In 2014, another measles outbreak linked to a religious community with high rates of under-immunized children in British Columbia reached 433 cases. Between December 2014 and April 2015, a large measles outbreak, which started at Disneyland in California, spread to half a dozen U.S. states, and into Canada and Mexico. In May 2016, NYC health officials confirmed an outbreak of 75 cases of varicella in an Orthodox Jewish community, where three quarters of those infected had not been vaccinated. In January 2017, an outbreak of mumps in Toronto surpassed 125 cases. Disease outbreaks rise and fall with almost cyclical regularity and are now standard fare in health related media coverage.

Reflecting on these cases, and focusing on Canadian coverage of the Disneyland outbreak in particular, we set out to examine the rhetorical construction of "anti-vaxxers", a pejorative term used to describe (and deride) people who oppose vaccination, and of the broader phenomenon of vaccine hesitancy. Vaccines represent a key bio-political technology through which the state seeks to impose some level of control over the health of individual bodies for the benefit of society. However, as immunization is not mandatory in Canada, the politics of vaccination can also be considered part of a wider project of moral regulation, in which states exercise power over individuals through a combination of normative practices and moral suasion (Lemke, 2002). In this context, outbreaks of infectious disease provide opportunities for reflecting on the connection between population health and moral politics, and of how media narratives that shape our understanding of these important moments can contribute to the creation of health pan- 
ics instead of fostering productive discussion about how to reduce vaccine anxiety.

\section{Moral Panics and Moral Regulation}

We draw in this study on classical treatments of moral panics as volatile moments characterized by heightened concern about a group, its conduct or a particular event; hostility against the perpetrators; disproportionality in the depiction of the threat; and a consensual reaction to it (Cohen 2002; Goode and Ben-Yehuda, 1994). In these situations some groups will be held up "as a threat to societal values and interests" (Cohen, 2002: 1) and in so doing become a target of hostility from political elites and the general population. Conventional studies in moral panic, therefore, focus on how authorities construct claims about these groups that amplify their putative threat, prompting social, political or other types of reactions directed against groups that are disproportionate to their actual level of risk (Hier, 2016b). These groups come to be clearly identified and perceived as 'folk devils' (Goode and Ben Yehuda, 1994), marginalized groups that embody the social anxieties of the dominant group (de Young, 2011). To the extent that a particular moral panic will take hold, therefore, depends on whether the discourse resonates with wider sociocultural anxieties (Cohen, 2002). For example, in the early 2000 s, media and other social actors generated a strong opposition to the use of ecstasy at rave parties, arguing that the young people who consumed the drug were not only vulnerable to its health effects but posed a threat to the wider population as well. Hier (2002) argues that rhetorical arguments based on medical claims about the health and wellbeing of youth were mobilized primarily to regulate their conduct and behaviour; therefore a symbolic threat was expressed in biomedical terms while responding to wider anxieties about youth cultural expression in which the panic took place.

Mass media play a key role in the development and formation of moral panics by magnifying the feelings of threat and fear that some groups represent to others (Garland, 2008). Media discourses stereotype and misidentify deviance, which, particularly in the case of health panics, can produce harmful representations that stigmatize certain groups. For example, during the 2003 SARS outbreak, Toronto media coverage depicted Chinese Canadians as both a biomedical and moral risk by associating this group with the origin of the outbreak in Hong Kong and directing fears and anxieties against them (Béland, 2011). 
In recent years, the scope of moral panic studies has broadened as scholars have re-imagined these cases not as moments of societal overreaction, but rather as rational responses to changing sociopolitical contexts (for example Hier 2011a, 2008, 2016b, Rohloff and Wright 2010, and Critcher 2009). This rethinking about what Hier described as the 'limits of moral panic' seeks to develop more robust analytical tools for understanding the interconnectedness between politics, culture and the forms of explicit and indirect social control that administer everyday life (Hier, 2011a, 2016b).

\section{From moral panic to moral regulation}

Moral regulation is prompted by anxiety caused by a sense of real or imagined crisis in the political and social order, and requires both self-regulation and the policing of others' conduct. Moral regulation discourses reproduce judgments about right and wrong ways of living and working, and reinforce the neoliberal imperative of self-governance. Risk is future-oriented and its moralization is associated with the possibility or calculated potential of harm; therefore, individuals are encouraged to be prudent and engage in responsible forms of risk management (Hier, 2016a, 2008) by taking ownership of their health and wellbeing, such as through diet and exercise, or in promoting and ensuring the health and wellbeing of their families, such as through vaccination. The social aspect of moral regulation projects are the "practices whereby some social agents problematize some aspect of the conduct, values or culture of others on moral grounds and seek to impose moral regulations on them" (Hunt, 1999: ix). In that sense, moral regulation discourses - articulated by authorities through messages of harm, risk, and personal responsibility - problematize the behaviour of others, while reaffirming one's own conduct and virtuousness (Hier, 2016b; Connel and Hunt, 2010).

Essential to projects of moral regulation is that mechanisms of "self-discipline should be generalized and disseminated" (Hunt, 1999: 215), it is not enough for individuals to act 'responsibly'-instead, there ought to be a general expectation for others to also behave in morally appropriate ways. Moral regulation projects are closely related to the concept of governmentality, which supposes both the ability to selfgovern and guide the conduct of others. Governmentality represents not a break from state power, but an extension of its work over individuals 'at a distance' (Rose and Miller, 2010), through interactions among state and extra-state agents, such as experts, journalists, and 
social movements, which play a crucial role in the volatility of moral politics (Hunt, 1999).

Hier $(2016 b, 2008)$ conceptualizes moral panics as rational claimsmaking processes in the context of neoliberal responsibilization, i.e., volatile manifestations of ongoing projects of moral regulation, where the 'moral' is constituted and naturalized by evoking practices of selfcare. In this sense, moral panic is understood as, "a short-term expression of routine moral regulation processes in everyday life - especially but not exclusively regulatory discourses that are transmitted through claims about risk, harm and personal responsibility" (2016b: 3). When these ruptures in routine practices or social mores occur, blame and responsibility for reducing harm is attributed to transgressive groups, who are perceived as putting society at risk. Deviant behaviours are responded to through defensive and coercive activities on behalf of the wider group, which then form a collective discourse of risk expressed through episodes of moral panic (Rohloff and Wright, 2010). Moralization is then conceptualized as a negotiation of social life and thus the crisis or panic is considered temporary and routine rather than structural and extraordinary.

Moral regulation is frequently expressed through discourses of health, nutrition, and medicine (Hunt, 1999), and moral panics can occasionally take the form of health scares, i.e., acute episodes of collective insecurity relating to issues that erupt suddenly, have limited duration, and fade quickly (Béland, 2011). Outbreaks of infectious disease, which are the focus of this study, fit this conceptualization well. While some take issue with the very term moral panic and question its linkage to health issues (see Critcher, 2008), health scares often involve expressions of both biomedical risk and moral danger. Some health scares require the presence of folk devils that will embody our projections of responsibility for why the episode has occurred. This is often the case during outbreaks of communicable illness. As with conventional understandings of moral panics, narratives that emerge through these events tend to be magnified and refracted in the media through stereotypical representations and dramatic discourses (Béland, 2011).

Vaccination is a key biomedical technology for for population health management and thus enables the state to exert some measure of control over bodies - not just for the benefit of individuals who are immunized, but for society more broadly (Connel and Hunt, 2010). Vaccination, however, is not mandatory in Canada and so it can be considered part of a project of moral regulation rooted in the concept of governmentality. In this context, individuals are expected to exer- 
cise self-governance and be responsible for their conduct and the risk posed by their children. Consequently, not vaccinating one's child is considered morally questionable behaviour that endangers not just the body politic but the societal project more broadly. Particularly in moments of acute risk, such as an outbreak of disease, the underlying anxieties associated with the smooth administration of societal projects can become exacerbated.

\section{Case and method}

On January 5, 2015, federal heath authorities were notified of five suspected cases of measles in California and Utah. All of the patients had visited the Disneyland theme park in California between December 17 and 28, 2014 (Centers for Disease Control and Prevention, 20 February 2015). For months, epidemiologists worked to trace and contain the highly contagious disease that would eventually spread to half a dozen U.S. states, and across the borders into Mexico and Canada. The outbreak eventually sickened 147 people in the U.S., and was declared over on April 17; however it remained active in the province of Quebec, where 159 people from a tight-knit religious community with low vaccination rates were also sickened. Although several people were hospitalized no deaths related to the outbreak were ever reported. (NBC, April 17, 2015).

We argue that the Disneyland outbreak provides an occasion to explore some of the tensions in moral regulation projects. The Disneyland outbreak was extensively covered in the international media for several months, before subsiding as case reports declined. We examined media coverage of the outbreak in leading national and regional agenda-setting Canadian newspapers, public affairs magazines and online news sites from December 2014 to April 2015. ${ }^{1}$ Our sample of 331 articles was collected in real time with Google Alerts and later verified against the Factiva database using a combination of relevant keywords (vaccin*, measles, anti-vaxx*, etc.). Similar sampling strategies were used directly at the online news websites. The final sample included hard news $(\mathrm{n}=161)$, editorials $(\mathrm{n}=52)$, columns $(\mathrm{n}=48)$, blog posts $(n=38)$, letters to the editor $(n=22)$, interviews $(n=6)$, op-eds $(n=3)$, and business report $(\mathrm{n}=1)$.

1. The analyzed news outlets include: The Walrus, The Halifax ChronicleHerald, The Globe and Mail, The National Post, The Winnipeg Free Press, The Ottawa Citizen, Toronto Star, Vancouver Sun, Medium, Huffington Post, and Vox. 
Our analysis specifically focuses on the framing of vaccines and depictions of parents opposed to vaccination. Mass media play a key role in shaping public understanding of public health issues broadly and vaccination specifically, and in providing a space for so-called moral entrepreneurs and moral regulators to express claims and grievances against those they deem a threat to public health. Thus, media discourses not only account for anti-vaccine beliefs and behaviours as a problem but also provide the discursive tools to discuss and make sense of the phenomenon of vaccine hesitancy. In particular, we examine how the label "anti-vaxxer" was applied broadly to account for any and all parents opposed to or anxious about vaccines. Although social media platforms play an important role in the construction of the anti-vaccination debate (Kata 2012, 2010; Bean 2011), most parents in Canada still rely on legacy media for timely and reliable information about vaccines and vaccine preventable diseases, especially during outbreaks (Greenberg et al., 2017).

Each news item was examined to identify the main topics, the actors involved, the activities they perform, and how they were characterized. Specifically the analysis focused, first, on the issues and themes that were considered significant in the outbreak coverage (e.g. spread and contagion, lack of vaccination, containment measures, etc.) and how this significance was expressed (in positive, negative or neutral terms). The themes were initially identified during a preliminary reading of the sample and additional themes were included as they emerged during the analysis (e.g. the impossibility to clearly identify "anti-vaxxers"). Second, we examined how different actors (e.g. government officials, health practitioners, parents, patients, etc.) were defined either in positive terms as part of the community $-U s$ or as a threat to social values and moral order-Other- (Gee, 2004). Third, we examined how activities and relationships between issues and actors were enacted (what each actor was portrayed as doing or expressing); what behaviours or beliefs were portrayed as good/bad, normal/abnormal, or positive/deviant (e.g. the portrayal of vaccination as a good, moral behaviour). Lastly, the coverage was examined to identify which sources/actors were invested with definitional authority, and therefore had a privileged voice in the stories, and which ones were marginalized and remained silent or absent.

After analysing each news item we identified broad, recurrent themes in the coverage as well as patterns regarding how different actors and activities were characterized, with particular attention to how vaccine hesitancy and vaccine hesitant parents were understood and portrayed, and how the 'anti-vaxxer' was constructed and deployed. 
Narrative is a core component of the news-making process. Our analysis examined the myriad ways that media coverage, "dislocates real world actions and events from their temporal sequence and re-embeds them topically into a condensed discourse" (Knight, 2001: 74), and our interest was to obtain an understanding of the ideological role that news media can play in how we make sense of events and issues, in particular the manner in which "the who, what, when, where, why and how of journalism" is enacted (ibid, 75).

\section{FindingS}

Pro-vaccination discourse: contagion fear and the hierarchy of credibility

Vaccines in general, and the measles-mumps-rubella (MMR) vaccine in particular, were framed in the media in righteous terms as offering protection against illness and having only minor and few risks that outweighed the dangers of infection; vaccination broadly was described as a form of 'protection' and a 'social responsibility' to one's children and community. Media coverage characterized measles unequivocally, as "extremely contagious" and a "killer disease" that can pose serious complications and life-long adverse effects.

Coverage of the Disneyland case typified what Wald (2008) calls "outbreak narratives": attention was given to investigating and proclaiming the origins of the disease, drawing a contrast between local and foreign cases by accounting for the networks through which diseases travel, chronicling the epidemiological work required to contain the disease, and establishing a narrative premised on a fear of contagion. This narrative was expressed principally through a discourse of risk and came to focus squarely on the social category of 'anti-vaxxers,' who were described as both a public health risk and existential threat to society. A pro-vaccine discourse dominated editorials, columns and op-eds, the discursive space in which news organizations are able to establish the normative terms of a social issue or problem by taking sides and proclaiming its status as a debate participant (Greenberg, 2000). Yet, this discourse was also evident in the hard news coverage, where a pro-vaccination position was reinforced by ensuring health officials maintained a prominent voice as the "primary definers" who occupied top billing in the story's "hierarchy of credibility" (Becker, 1967). Medical and official sources were quoted far more extensively than others, and their views on the importance of vaccination were consistent and clear: vaccines save lives, and the decision 
of parents to refuse or delay vaccination puts communities at risk. For example, in the following excerpts then-Prime Minister Stephen Harper, and the ministers of health for Canada and the province of Ontario are quoted in favour of vaccinations:

We have a responsibility when it comes to this, not just a responsibility to vaccinate our children which I think every parent has a responsibility to do, and not just a responsibility to encourage that widespread vaccination so we're not putting other kids at risk. (PM unveils foreign vaccination funding, chides anti-vaxxers. February 16, 2015)

"If you don't immunize your children and you send them to school potentially ill or exposed another child who may be more vulnerable than your own is at even a greater risk and that's what concerns me the most," (the federal health minister) told an unrelated news conference Tuesday. She called vaccines miracles of modern medicine that save lives. (Health minister speaks out on use of vaccines, January 30, 2015)

"It is important for people to be fully immunized against this serious disease; it's the best way to prevent measles and its spread," (Ontario's Health Minister and Ontario's acting chief medical officer of health) said in a statement. "We are urging Ontarians to ensure all their immunizations for measles and those of their children are up-to-date, not only to protect them from this disease, but those around them. Parents who do not get their kids immunized are putting other children at risk." (Branswell, February 11, 2015)

Critics of vaccination, on the other hand, were largely discredited and dismissed as irrational, opposed to science, and thus lacking in definitional credibility. For example,

[Jenny] McCarthy, a former Playboy model turned pop immunologist, has made it her mission to connect autism and childhood vaccinations. There is no medical evidence to back this connection, of course. This is a mission powered by junk science, anecdotal tales, gut feelings and widely debunked studies (Menon, February 5, 2015).

CBC pundit Rex Murphy also weighed in to the anti-vaccination debate by eviscerating actress Jenny McCarthy and her "fellow neurosurgeons on "The View"'.

"They've confessed to have the intellectual power of a dead tree stump and many even living in one," the CBC News pundit says (...) "Not vaccinating a child amounts to taking a free ride on the good practices of others. Their good practice is the real protection against your immense carelessness," he says. (Lum, February 6, 2015). 
Similarly, Globe and Mail columnist John Doyle (24 March, 2015) described vaccine hesitant parents as characters from a bygone era of scientific darkness and ignorance:

While we are, as a culture, horrified by fundamentalism that wants to take the world backward, back beyond the Age of Enlightenment, we have tended to tolerate those in our culture who reject modern medicine and, essentially plan to take public health back by decades.

In the main, therefore, voices from within the media avoided the trappings of providing 'false balance, i.e. giving equal space to expert scientific knowledge and non-expert opinions and claims. Instead they offered more definitional authority to qualified sources, who spoke to the established science of vaccination, than to voices without technical or medical expertise (Dixon and Clarke, 2013). Furthermore, avoiding false balance was directly addressed on three occasions. The first was in an editorial in The Globe and Mail responding to a reader's accusation that outbreak coverage did not include anti-vaccination arguments:

Would you even report a story about whether the Earth is flat or round and quote some marginal conspiracy theory types arguing that it can't be round? No. (...) The same is true for the anti-vaccine movement. There is no equivalency between the scientific evidence of many studies and perhaps an actress whose beliefs are based on - well, who knows really. (Stead, February 18, 2015).

Columns in the Ottawa Citizen and the Toronto Star presented similar arguments against false balance:

Of course, there are no "two sides" in the matter of vaccinations; no "debate" to be had. There are proven, irrefutable facts regarding the safety and efficacy of vaccination, and there are lies. It's that simple. Still, the afflicted enthusiastically appear on-air, armed with "research" acquired while earning a $\mathrm{PhD}$ in epidemiology from Google University. They offer "alternative" theories of disease, complete with "alternative" remedies like homeopathic nosodes. (Read: expensive placebos; snake oil.) (Picazo, February 10, 2015).

There is no need for "balance". There is no reason for "choice." Because believing in anti-vaccination is an indefensible position. The benefit of vaccinating yourself against infectious diseases isn't a theory of proposition or a position. It's a fact. There's no reason to even "debate" the issue. (Semley, February 9, 2015). 
People who oppose vaccination accounted for $13 \%$ of the sources used in the coverage $(n=104)$. In most cases, however, these oppositional voices were discredited as the following example shows:

"I don't care about Jenny McCarthy, she has no impact in my life. I don't have meetings with anti-vax people. It's just me and my husband making a decision based on a lot of research and it has nothing to do with Jenny McCarthy." (...) Like many who oppose immunization, the Ottawa mother is in contact with some other parents and has found numerous sources of information to support her concerns about the safety of vaccines. (Payne, March 21, 2015)

Other sources included health organizations (24\%), medical sources (13\%), parents (11\%), academics (11\%), federal and provincial sources (12\%). The remaining $16 \%$ included media figures, pharmaceutical representatives, natural health providers, school board officials, pollsters and patients.

\section{Spectre of the 'anti-vaxxer'}

The media portrayed parents of non-vaccinated children as a threat to public health and thus to society more generally, and they were overtly blamed for the measles outbreak. News reports rarely employed the technical term "vaccine hesitant", which has become the lingua franca among public health researchers to describe the broad spectrum of vaccine beliefs and behaviours ranging from strident opposing views to nervousness coupled with decisions to vaccinate (Dubé et al., 2013; Greenberg et al., 2017). Rather, in keeping with the norm that media narratives should be simple and clear, the coverage relied on the more colloquial concept of "anti-vaxxers", a pejorative term used to describe all parents of nonvaccinated or under-vaccinated children. For example, the National Post referred to 'anti-vaxxers' as "criminals" (Potter, February 21, 2015) who were trying to "recruit other parents in the dangerous campaign against childhood vaccinations" (A better shot at keeping kids safe, February 10, 2015). Additionally, the coverage depicted non-vaccinators as anxious, scared, selfish, and ignorant:

Though privilege certainly plays a big role in the anti-vaccination ethos, it's fear that is the driving force here - fear that is often exacerbated by a deep-seated mistrust of The Man in whatever iteration they choose: Big Pharma, the government, medicine in general (Zoratti, February 4, 2015)

No matter how much or often anti-vaccination zealots try to trivialize this disease, measles is not just another mild childhood illness. In places in the world where immunizations are sporadic, tens of thousands of preschool kids are killed or maimed by measles, each and every year. That's a fact. (Schneidereit, January 17, 2015) 
That Crosby had the shot and still was affected by the virus may wind up serving as ammunition for anti-vax activists, who'll add "it doesn't even work" to the pile of ridiculous, discredited arguments against vaccination (e.g. vaccines are so toxic they do more damage than good, they cause autism, etc.). They're the main reason viruses such as the mumps, measles and other illnesses that had been all but eradicated are appearing all over the place again. (Crosby illness a reminder to get vaccinated, December $19,2014)$

Based on these depictions, journalists, columnists and other commentators called on policy makers to make vaccinations mandatory:

We have all kinds of laws in place to protect children and allow them to flourish. Parental freedom does not extend to corporal punishment, and school attendance is mandatory, to cite just two examples. Similarly, parents should not be allowed to deny children the protection of vaccines. (Picard, February 3, 2015).

More coercive measures may be required to persuade parents who are opposed to vaccinations to have their children immunized, according to a health sciences professor at Simon Fraser University (...) "I think we need to have a conversation about compulsory vaccinations (...) we can't just say 'well, we tried and couldn't change people's behaviour' if that behaviour is causing other people to become ill and essentially dying". (Shore, February 17, 2015)

Data collection must go hand-in hand with policies that make it more difficult to opt out of vaccinations (...) link child tax credits and other benefits to proof of vaccination. Policy-makers should no longer enable such reckless behavior. (Booster shot needed for vaccination regime, March 20, 2015).

\section{Profiling the "anti-vaxxer"}

From mods and rockers to young black men, homosexuals, and homeless youth, folk devils have historically had specific, visible identities reflecting their social, class or ethnocultural status; however, identifying them as the embodiment of collective anxiety and the object of moral approbation and regulation can be difficult. Risk related fears expose complex institutional and political relations, which diffuses issues of responsibility, representation, and blame (de Young, 2011). In the case of vaccine hesitant parents, this identity is more diffused and less obvious. A common feature of the Disneyland outbreak coverage thus involved an effort by numerous media to profile 'anti-vaxxers' in an attempt to render them more visible and identifiable as a social group. Indeed, part of what 
constituted their threat potential was the notion that they could be just about anyone living just about anywhere. For example, for the National Post "anti-vaxxers" were not just a fringe of devout religious adherents, but "well-educated, prosperous, organic-eating urbanites" (Canada's vaccine strategy isn't working, February 17, 2015). Similar observations were made in other media outlets:

We assumed that this must be a marginal group (...) Then we started to see the numbers. It wasn't back-to-the-land types or destitute cat ladies driving this trend (but by) wealthy, elite, educated families. This is really bad (...) the vaccination culprits are not the wild-eyed zealots who don't open their doors, but people you know (Saunders, February 7, 2015).

Thus, key to the rhetorical construction of 'anti-vaxxers' as folk devils were efforts to subject them to caricature and ridicule. As Globe and Mail columnist Tabatha Southey wrote, "Could we stop anti-vaxxers if measles contained gluten?" (February 7, 2015). Another opined that anti-vaxxers are "parents who claim that they will keep measles at bay by feeding their children organic food and channeling their chakras" (Lye, March 13, 2015), and a third described anti-vaxxers as worse than terrorists: "Even ISIS supports getting kids vaccinated" (Fisher, Feburary 2, 2015).

However, precisely identifying who "anti-vaxxers" are was difficult because of the lack of clear socio-demographic characteristics common across this highly diffused group. Faced with this difficulty, some media moved beyond oversimplified representations of "antivaxxers". For example, the Ottawa Citizen challenged the notion that "anti-vaxxers" are dupes of the pharmaceutical industry who lack knowledge and sophistication, and drew on recent survey research to show how vaccine hesitant parents are better educated, wealthy, and "more involved in their children's upbringing and health" (Payne, December 4, 2014). The digital news site Vox provided a nuanced discussion of the issue by describing differences between "anti-vaxxers", who indignantly oppose vaccination, and vaccine delayers who "delay some (vaccines), and skip others. They think their self-styled schedules are safer than the one approved by the government" (Belluz, March 2, 2015). The article, written by Julia Belluz, a health and science specialist, also explained that "delayers...far outnumber the deniers", thus clarifying that total rejection of vaccines is uncommon. Furthermore, the Toronto Star sought to complicate the "anti-vaxxer" problem by arguing that "attributing the rise of the anti-vaccination movement to a single fear or social class" ignores its history (King, February 23, 2015). 
The discursive flexibility of the term "anti-vaxxer" also complicated the narrative requirement of moral panic to identify a clear group of deviants to become the focus of collective problematization. This absence led some reporters to concede that vaccine hesitancy has different sociocultural expressions. Unlike other folk devils who have clear physical or psychological characteristics (e.g. race, religion, organized group), "anti-vaxxers" exist across social classes, racial groups, education levels, and political affiliations -this heterogeneity complicated their demonization. Yet, this definitional uncertainty increased the feelings of threat posed by parents who do not vaccinate or even consider not vaccinating their children:

There's no profile for these individuals... It's everybody. It's you and me... It could be your neighbour. That's the scary thing. Without asking someone, without asking other parents at your kids' schools or asking people at your daycare, you're not really going to know (Brean, March 9, 2015).

\section{'Anti-vaxxers' as a moral threat}

The Disneyland outbreak could be characterized as a case of moral panic to the extent that it generated a consensual, volatile and disproportionately hostile reaction to a particular group, however difficult it may have been to identify the membership of that group (Goode and Ben Yehuda, 1994). Indeed, the media narrative contained key features of moral panics: (a) concern about a conduct or practice, (refusing vaccinations); (b) hostility against the perpetrators("anti-vaxxers"); (c) consensus in the reaction, (the threat must be stopped); (d) disproportionality in the depiction of the threat, ("anti-vaxxers" are a large and growing group); and (e) volatility of the episode, (media reporting and a period of intense anxiety emerged quickly and then dissipated). However, anxiety about vaccination from some segments of the population are not a new phenomenon -indeed, as noted above, fears about vaccines are as old as the science of immunization itself. Opposition to vaccines began with the imposition of mandatory vaccination in England (Durbach, 2005), and vaccine hesitancy has since represented a persistent source of worry and risk that flares up in moments of perceived crisis or threat, particularly during outbreaks of disease. The response generated by the Disneyland outbreak can thus be considered not a moral panic per se, but an acute moment of anxiety in an ongoing process of moral regulation (Hier, 2008).

Understood this way, media narratives framed vaccination as a mode of desirable citizenship and 'moral' conduct requiring both a 
commitment to self-governance and to protecting community wellbeing. The depiction of vaccination as a social responsibility hinged on the notion that individuals should govern their own bodies, and those of their children, and that a range of techniques for governing the conduct of others was also important. News reports and opinion pieces argued that, "vaccines are not just about your child" (Clarke, February $12,2015)$; and "vaccination is not a personal decision. It's a social obligation" (Kliff, January 31, 2015).

Parents described as "anti-vaxxers" were depicted as a threat to the social and moral order, as deviants whose behaviour demanded public acts of disapproval (demonization, vilification, mockery) combined with calls for state regulation. These depictions did not sufficiently capture the complicated relationship between coexisting forms of responsibility (Hier, 2016b), namely the duty of authorities to maintain community health and the duty of parents to act in their children's best interest. The coverage thus featured the discussion of myriad solutions to the "anti-vaxxer problem": federal and provincial vaccine registries, mandatory vaccination policies, improvements to the national vaccine schedule, banning the commercialization of homeopathic remedies purporting to be "natural vaccines", and making vaccination exemptions harder to get where vaccines are mandatory for schoolchildren.

\section{Conclusion}

The measles outbreak that began at Disneyland and spread across the United States and into Canada and Mexico focused public attention to the issue of vaccination in a significant way. Exacerbated and magnified by the media, coverage of the outbreak focused blame onto parents of unvaccinated children and involved calls for state action to restore order The coverage subscribed to the notion of personal and social responsibility found in projects of moral regulation, and amplified the risk to public health by focusing on "anti-vaxxers" as a deviant and threatening group. Although childhood vaccination rates in Canada are generally stable (Greenberg et al., 2017), there remains a stubborn minority of parents (between 2-4\%) who refuse to have their children vaccinated. A larger, growing group of "vaccine hesitant" parents presents a more difficult and complex dilemma for the public health community. In this case, media coverage stripped the problem of vaccine hesitancy of its complexity by emphasizing a discourse of blame and shame. Media not only actively participated in the construction of a health scare bordering on moral panic, it also provided a venue for 
denouncing parents who hold anti-vaccine views as a broader threat to society

While there are numerous reasons for why parents may be vaccine hesitant, media coverage of the Disneyland outbreak only partially acknowledged this variability and instead focused on the most strident opponents of vaccination. Parents of children who are not vaccinated were scrutinized and subjected to expert concern and assessment. The coverage generally failed to capture the broad range of views held by vaccine hesitant parents, thus amplifying the actual threat posed by those who hold strident anti-vaccine views. While there were notable exceptions, news coverage that captured the complexity of this phenomenon came from only a small group of specialist health and science reporters. Media coverage arguably contributed to further polarizing of the vaccine debate by obscuring the complex and varied political, economic, and social causes for decreasing rates of full immunization coverage. Arguably, and with some notable exceptions, the coverage did little to advance public understanding of vaccine hesitancy as a complex public health problem.

There are three key implications of our research. First, media coverage of disease outbreaks has largely moved away from the "false balance" model of reporting, in which journalists position pro-vaccine and anti-vaccine advocates against each other as though each position has equal weight and value. This model has been critiqued for continuing to raise skepticism about established scientific issues, from climate change to vaccination (Dixon and Clarke, 2013). Yet, despite the slow disappearance of anti-vaccine advocates as active sources in the coverage, the "anti-vaxxer" looms large as a central character in the outbreak narrative. Yet, despite the slow disappearance of the anti-vaccine advocate as active sources (i.e., those who speak for themselves), the 'anti-vaxxer' looms large as a central character in the outbreak narrative. We contend that the 'anti-vaxxer' is no longer a useful category. While this is important for all of us to understand, it is particularly critical for journalists and public health officials.

Second, the highly moralized tone of outbreak reporting may be a double edged sword. On the one hand, it may serve a productive role in constituting a sense of moral righteousness on the part of pro-vaccine advocates, who value and believe in the importance of immunization for population health protection. This sense of certainty is culturally important to maintaining levels of immunization that health officials note are necessary for herd immunity. Yet, at the same time, the tone of the coverage risks cementing the views of those parents who remain strongly opposed to vaccination, and potentially alienating the 
growing numbers of other parents who are anxious about vaccines and looking for voices of understanding and not moral approbation. Worried parents who may have legitimate questions about vaccine safety and effectiveness, regardless of the reasons underpinning those questions, may be less likely to raise them publicly for fear of censure and stigmatization, and more likely to seek support from those parents who may share their concerns or seek to benefit from them. In other words, shaming may have the effect of disconnecting an individual from the moral community and forcing them to seek kinship elsewhere.

Third, outbreaks generate opportunities for public health officials to shape the structure and tone of media and public discourse. As the "anti-vaxxer" remains a dominant character in the media narrative, public health officials may find themselves implicated (by their own words or through association) in the construction of a moral panic about vaccine hesitancy. Here, health officials may be blaming a group that does not actually exist, and in doing so oversimplify the complex causes of declining vaccination rates. These causes include not just attitudes and beliefs about vaccine safety, but also vaccine scheduling, province-specific recommendations about types of immunization, low levels of health literacy relating to socioeconomic disadvantage, and so on. Therefore, greater attention to the importance of narrative, and of strategic communication generally, is needed to reduce polarization and advance the debate in a more constructive manner.

This study focused on the discursive construction of "anti-vaxxers" in print and online mainstream media; further research could explore how these narratives influence or drive public debates on vaccination and vaccine hesitancy in social media. For example, Facebook and Twitter are important fora for shaping how new parents seek, use and discuss information about vaccines, and has been identified as playing an important role in disseminating anti-vaccine information (e.g., Mitra, Counts and Pennebaker, 2016). Moreover, social media sites have become crucial hubs for supporting the distribution and circulation of news reports from the legacy media. Future research can build fruitfully upon this study in exploring how the ever-changing mediascape provides new opportunities or challenges to the formation and contestation of outbreak narratives. 


\section{REFERENCES}

A better shot at keeping kids safe. February 10, 2015. Winnipeg Free Press: A6.

Bean, Sandra J. 2011. Emerging and continuing trends in vaccine opposition website content. Vaccine, 29(10): 1874-1880.

Becker, Howard S. 1967. Whose Side Are We On? Social Problems, 14(3): 23947.

Béland, Daniel. 2011. The unhealthy risk society: Health scares and the politics of moral panic. In Hier, S (Ed.), Moral Panic and the Politics of Anxiety (pp. 225-235). New York: Routledge.

Belluz, Julia. March, 2, 2015. The vaccine delayers: They hate anti-vaxxers - but don't quite vaccinate on time. Vox. URL: http://www.vox. com/2015/2/6/7988715/the-vaccine-delayers-they-hate-anti-vaxxersbut-dont-quite-vaccinate

Blume, Stuart. 2006. Anti-vaccination movements and their interpretations. Social Science and Medicine, 62(3): 628-642.

Booster shot needed for vaccination regime. March 20, 2015. Vancouver Sun: B6.

Branswell, Helen. February 11, 2015. Quebec measles cases related to California outbreak. The Chronicle Herald. URL: http://thechronicleherald.ca/ canada/1268632-quebec-measles-cases-related-to-california-outbreak

Brean, Joseph. March 9, 2015. No single profile fits vaccine opponents; All types of Canadians show some skepticism. Ottawa Citizen: C1.

Canada's vaccine strategy isn't working. February 17, 2015. National Post: A8.

Centers for Disease Control and Prevention. February 20, 2015. Measles Outbreak - California, December 2014-February 2015. Morbidity and mortality weekly report. URL: http://www.cdc.gov/mmwr/preview/mm$\mathrm{wrhtml} / \mathrm{mm} 6406 \mathrm{a} 5 . \mathrm{htm}$ ? s_cid= $\mathrm{mm6406a5} \mathrm{w}$

Clarke, Katrina. February 12, 2015. Baby's measles scare goes viral on Facebook; Mother's angry post slamming 'anti-vaxxers' strikes a nerve. Toronto Star: GT1.

Cohen, Stanley. 2002. Folk Devils and Moral Panics: The Creation of the Mods and Rockers. ( $\left.3^{\text {rd }} \mathrm{edn}\right)$. London: Routledge.

Connel, Erin and Hunt, Alan. 2010. The HPV Vaccination Campaign: A Project of Moral Regulation in an Era of Biopolitics. Canadian Journal of Sociology, 35(1): 63-82.

Critcher, Chas. 2008. Widening the focus: Moral panics as moral regulation. British Journal of Criminology, 49(1):17-34. doi:10.1093/bjc/azn040

Crosby illness a reminder to get vaccinated. Vancouver Sun, December 19, 2014 : B8. 
De Young, Mary. 2011. Folk devils reconsidered. In Hier, SP (Ed.), Moral Panic and the Politics of Anxiety (pp. 118- 133). New York: Routledge.

Dixon, Graham N. and Clarke Christopher. 2013. Heightening Uncertainty Around Certain Science: Media Coverage, False Balance, and the Autism-Vaccine Controversy. Science Communication, 35(3): 358-82.

Doyle, John. March 24, 2015. Watch The Vaccine War and get very, very upset. Globe and Mail: L2.

Dubé, E., Laberge, C., Guay, M., Bramadat, P., Roy, R., \& Bettinger, J. A. (2013). Vaccine hesitancy: An overview. Human Vaccines \& Immunotherapeutics, 9(8): 1763-1773. https://doi.org/10.4161/hv.24657

Durbach, Nadja. 2005. Bodily matters: The anti-vaccination movement in England, 1853-1907. Durham, NC: Duke University Press.

Fisher, Max. February 2, 2015. Even ISIS supports getting kids vaccinated. Vox. URL: http://www.vox.com/2015/2/2/7966421/vaccination-isis

Garland, David. 2008. On the concept of moral panic. Crime, Media, Culture: An International Journal, 4(1): 9-30. doi:10.1177/1741659007087270

Gee, James P. 2004. An Introduction to Discourse Analysis: Theory and Method. London: Routledge.

Goode, Erich and Ben-Yehuda, Nachman. 1994/2009. Moral panics: The social construction of deviance ( $2^{\text {nd }}$ edn.). Chichester, U.K; Malden, MA: Wiley-Blackwell.

Greenberg, J., Dubé, E., \& Driedger, M. (2017). Vaccine Hesitancy: In Search of the Risk Communication Comfort Zone. PLoS Currents, 9. doi:10.1371/ currents.outbreaks.0561a011117a1d1f9596e24949e8690b

Greenberg, J. (2000) Opinion discourse and Canadian newspapers. Canadian Journal of Communication, 25(4): 517-37.

Hausman, Bernice, Ghebremichael, Mecal, Hayek, Philip, and Mack, Erin. 2014. 'Poisonous, filthy, loathesome, damnable stuff': The rhetorical ecology of vaccination concern. Yale Journal of Biology and Medicine, 87: 403416.

Health minister speaks out on use of vaccines. January 30, 2015. National Post: A4.

Henderson, Deborah. 1997. The Miracle of Vaccination. Notes and Records of the Royal Society of London, 51(2): 235-45.

Hier, Sean P. 2002. Raves, risks and the Ecstasy panic: A case study in the subversive nature of moral regulation. Canadian Journal of Sociology, 27(1): 33-57.

Hier, Sean P. 2008. Thinking beyond moral panic: Risk, responsibility, and the politics of moralization. Theoretical Criminology, 12(2): 173-190. doi:10.1177/1362480608089239 
Hier, Sean P. 2011a. Tightening the focus: Moral panic, moral regulation and liberal government. The British Journal of Sociology, 62(3): 523-541. doi:10.1111/j.1468-4446.2011.01377.x

Hier, Sean P. 2011b. Introduction. Bringing moral panic studies into focus. In Hier SP (Ed.), Moral Panic and the Politics of Anxiety (pp. 1- 19). New York: Routledge.

Hier, Sean P. 2016a. Moral panic, moral regulation, and the civilizing process. The British Journal of Sociology, 67(3): 414-434.

Hier, Sean P. 2016b. Good moral panics? Normative ambivalence, social reaction, and coexisting responsibilities in everyday life. Current Sociology. Available from: http://csi.sagepub.com/cgi/doi/10.1177/0011392116655463

Hunt, Alan. 1999. Governing morals: a social history of moral regulation. Cambridge, UK ; New York: Cambridge University Press.

Kata, Anna. 2012. Anti-vaccine activists, Web 2.0, and the postmodern paradigm - An overview of tactics and tropes used online by the anti-vaccination movement. Vaccine, 30(25): 3778-3789.

Kata, Anna. 2010. A postmodern Pandora's box: Anti-vaccination misinformation on the internet. Vaccine, 28(7): 1709-1716.

King, Robin L. February 23, 2015. Inside the mind of anti-vaxxers. Toronto Star.

Kliff, Sarah. January 31, 2015. Christie is wrong. Vaccination is not a personal decision. It's a social obligation. Vox. URL: http://www.vox. $\underline{\text { com/2015/1/31/7955947/vaccination-herd-immunity }}$

Knight, Graham. 2001. Prospective News: press pre-framing of the Ontario public service strike. Journalism Studies, 2(1): 73-91.

Lemke, Thomas. 2002. Foucault, Governmentality, and Critique. Rethinking Marxism, 14(3): 49-64.

Lum, Zi-Ann. February 6, 2015. Rex Murphy: Anti-Vaxxers have 'the intellectual power of a dead tree stump. Huffington Post Canada. URL: http://www. huffingtonpost.ca/2015/02/06/rex-murphy-anti-vaccine_n_6631184. $\underline{\mathrm{html}}$

Lye, Harriet. March 13, 2015. Dear Anti-Vaxxers: I Believe in Western Medicine Because it Saved My Life. Huffington Post. URL: http://www.huffingtonpost.ca/harriet-alida-lye/anti-vaccine b 6863604.html

Menon, Vinay. February 5, 2015. Measles and an outbreak of stupidity. Toronto Star: E5.

Mitra, Tanushree, Counts, Scott, Pennebaker, James W. 2016. Understanding Anti-Vaccination Attitudes in Social Media. In ICWSM, pp. 269-278. URL: http://comp.social.gatech.edu/papers/icwsm16.vaccine.mitra.pdf

NBC News (2015, April 17) Measles Outbreak Traced to Disneyland is Declared Over. Retrieved October 19, 2016, from http://www.nbcnews.com/story- 
line/measles-outbreak/measles-outbreak-traced-disneyland-declaredover-n343686

Payne, Elizabeth. December 4, 2014. Researchers seek to understand rise of antivaccine movement. Ottawa Citizen: A4.

Payne, Elizabeth. March 21, 2015. Son's allergies, not autism, worry this local anti-vaxxer. Ottawa Citizen: C3.

Picard, Andre. February 3, 2015. Vaccination is for the greater good. The Globe and Mail: A13.

Picazo, Alheli. February 10, 2015. The scourge of science denialism hard to contain; There are no 'two sides' to this issue. Ottawa Citizen: C4.

PM unveils foreign vaccination funding, chides anti-vaxxers. February 16, 2015. The Globe and Mail: A4.

Potter, Andrew. February 21, 2015. The anti-science epidemic; We live in a world where we happily play with our smartphones all day and worry all night about the rays they give off. National Post: A11.

Riedel, Stephan. 2005. Edward Jenner and the history of smallpox and vaccination. Baylor University Medical Center. Proceedings, 18(1): 21-25.

Rohloff, Amanda and Wright, Sarah. 2010. Moral panic and social theory: Beyond the heuristic. Current Sociology, 58(3): 403-419. doi: 10.1177/0011392110364039

Rose, Nikolas and Miller, Peter. 2010 Political power beyond the State: problematics of government. The British Journal of Sociology, 61: 271-303. doi:10.1111/j.1468-4446.2009.01247.x

Saunders, Doug. February 7, 2015. Shunning vaccines and the census - a slap in the face of citizenship. The Globe and Mail.

Schneidereit, Paul. January 17, 2015. Past scourge of measles ancient history to many. Halifax Crhonicle Herald.

Semley, John. February 9, 2015. Inoculating against idiocy. Toronto Star: A11.

Shore, Randy. February 17, 2015. Vaccination should not be discretionary: expert; More coercive measures needed, professor says. Vancouver Sun: A4.

Southey, Tabatha. February 7, 2015. Could we stop anti-vaxxers if measles contained gluten?" The Globe and Mail: F3.

Stead, Sylvia. February 18, 2015. Stories on vaccination aren't propaganda; The Globe's news stories and columns provide a balanced point of view. The Globe and Mail.

Wald, Priscilla. 2008 Contagious: Cultures, Carriers, and the Outbreak Narrative. Durham, NC: Duke University Press.

Zoratti, Jen. February 4, 2015. Anti-vaccination ignorance feeds autism fears. Winnipeg Free Press: B1. 


\section{Funding}

The Canadian Institutes of Health Research (CIHR) provided funding for this research through a grant administered by the Canadian Immunization Research Network.

Gabriela Capurro is a $\mathrm{PhD}$ candidate in Communication at Carleton University. Her research focuses on risk and health communication, particularly outbreak discourses related to viral and bacterial infections. Her dissertation research analyses the social and rhetorical construction of antimicrobial resistance as a public health risk. She holds a SSHRC doctoral award. She worked as a researcher at the Concordia Science Journalism Project (Montreal) where she focused on public perception of new technologies.

E-Mail: gabrielacapurro@cmail.carleton.ca

Josh Greenberg is Director of the School of Journalism and Communication at Carleton University. His research examines media representations of outbreaks, and corporate, government and NGO risk communication strategies and campaigns. In addition to his scholarship, Dr. Greenberg has provided research support and advice to the World Health Organization and Public Health Agency of Canada, and served as an expert panelist for the Council of Canadian Academies and National Academies of Science, Engineering and Medicine.

\section{E-Mail: $\underline{\text { Joshua.Greenberg@carleton.ca }}$}

Eve Dubé is a medical anthropologist and a researcher at Quebec National Institute of Public Health and the Research Center of the CHU de Quebec-Université Laval. Her research focuses on the socio-cultural aspects of vaccination. She is interested in vaccine hesitancy and doing various related projects. She was a member of the WHO working group on Vaccine Hesitancy. Since 2014, she leads the Social Sciences and Humanities Network (SSHN) of the Canadian Immunization Research Network.

E-Mail: Eve.Dube@inspq.qc.ca

S. Michelle Driedger is a Professor and Tier II Canada Research Chair in Environment and Health Risk Communication, in the Department of Community Health Sciences, at the University of Manitoba, and a member of the Social Sciences and Humanities Network with the Canadian Immunization Research network. Her program of research examines harms and benefit communication in primary care and public health, with a specific focus on vaccination decisions.

E-Mail: Michelle.Driedger@umanitoba.ca 
48 C) Canadian Journal of Sociology/Cahiers canadiens de sociologie 43(1) 2018 